\title{
PENGGUNAAN MODEL PEMBELAJARAN KOOPERATIF TIPE THINK- PAIR-SHARE DISERTAI DEMONSTRASI UNTUK MENINGKATKAN AKTIVITAS DAN HASIL BELAJAR BIOLOGI KELAS XII SMK PGRI 1 TERBANGGI BESAR
}

\author{
Hesty Wahyuningsih \\ Pendidikan Biologi, STKIP Tunas Palapa, hesty wahyuningsih@ymail.com
}

\section{INFO ARTIKEL}

Riwayat Artikel:

Diterima: 07-04-2018

Disetujui: 20-04-2018

\section{Kata Kunci:}

Kooperatif Tipe Think-

Pair-Share

Demonstrasl

Aktivitas

Hasil Belajar

\begin{abstract}
ABSTRAK
Abstrak: Penelitian ini adalah Penelitian Tindakan Kelas (PTK), bertujuan meningkatkan aktivitas dan hasil belajar biologi sebanyak 21 peserta didik yang memiliki tingkat kemampuan yang bervariasi. Peneliti mengamati secara langsung selama 2 siklus. Setiap siklus mempunyai tahapan-tahapan yaitu perencanaan, pelaksanaan tindakan, observasi dan refleksi. Teknik pengumpulan data menggunakan lembar observasi dan tes. Hasil penelitian menunjukkan bahwa penggunaan kooperatif tipe think-pair-share disertai demonstrasi dapat meningkatkan aktivitas dan hasil belajar. Peningkatan aktivitas terlihat pada setiap indikator aktivitas. Peserta didik yang dinyatakan mencapai KKM (nilai $\geq 75$ ) pada siklus I sebesar $76,19 \%$ dan pada siklus II meningkat menjadi 90,84\%. Saran yang diajukan kepada guru agar aktivitas dan hasil belajar memperoleh hasil yang optimal, maka disarankan untuk menerapkan model kooperatif tipe think-pair-share disertai demonstrasi.
\end{abstract}

\begin{abstract}
This research is a Classroom Action Research (PTK), aims to increase the activity and biology learning outcomes as many as 21 students who have varying ability levels. Researchers observed directly for 2 cycles. Each cycle has stages of planning, implementation of action, observation and reflection. Data collection techniques use observation and test sheets. The results showed that the use of cooperative type of think-pair-share with demonstration can increase activity and learning outcomes. Increased activity is seen in each activity indicator. Students who declared to reach $K K M$ (value $\geq 75$ ) in the first cycle of $76,19 \%$ and in the second cycle increased to 90,84\%. Suggestions submitted to the teacher for activities and learning outcomes to obtain optimal results, it is advisable to apply the model of cooperative type of thinkpair-share with the demonstration.
\end{abstract}

\section{A. LATAR BELAKANG}

Pendidikan merupakan salah satu faktor penting dalam perkembangan dan pembangunan suatu negara. Negara dikatakan maju dalam segala bidang baik dalam bidang ekonomi, teknologi, pertanian ataupun yang lainnya tidak terlepas dari peran pendidikan. Hal ini dikarenakan orang cerdas atau berpendidikan akan dapat memberikan kontribusi yang positif kepada negara. Akan tetapi yang perlu diingat bahwa pendidikan akan berhasil dengan maksimal manakala setiap elemen dari pendidikan baik dari bawah sampai atas senantiasa berorientasi pada tujuan pendidikan nasional. Adapun tujuan pendidikan nasional adalah untuk berkembangnya potensi peserta didik agar menjadi manusia yang beriman, bertakwa kepada tuhan yang maha Esa, berakhlak mulia, sehat, berilmu, cakap, kreative, mandiri, dan menjadi warga negara yang demokratis serta bertanggung jawab.

Menjawab tuntutan tersebut, dewasa ini telah banyak dilaksanakan kegiatan-kegiatan yang berkaitan dengan peningkatan mutu pendidikan nasional. Hal ini dapat kita lihat dengan banyaknya usaha-usaha perubahan dan perbaikan-perbaikan pada sistem pendidikan. Dimana usaha perbaikan dan perubahan ini mencakup dari berbagai aspek seperti: kebijakkan, kurikulum, segi matrial, kesejahteraan para guru dan penempatan guru profesional di daerah terpencil.

Guru sebagai tenaga pendidikan harus dapat mengembangkan potensi peserta didik secara optimal dengan kemampuan untuk berkreasi, mandiri, bertanggung jawab, dan dapat memecahkan masalahmasalah yang dihadapi, sehingga nantinya dapat melaksanakan fungsinya sebagai warga negara. Dalam memberdayakan peserta didik secara optimal maka tidak terlepas dari pembelajaran yang sesuai dengan karakteristik peserta didik.

Proses pembelajaran yang terjadi di dalam kelas sebaiknya tidak hanya didominasi oleh guru saja, akan tetapi harus peserta didik yang lebih aktif karena memang peserta didik yang belajar bukan guru, sehingga peserta didik tidak lagi sebagai objek belajar akan tetapi sebagi subjek belajar. Jadi jelaslah bahwa memang 
peserta didik yang harus berperan aktif dalam proses pembelajaran untuk mendapatkan dan mengembangkan pengetahuan itu, sementara peran guru bukan sebagai satu-satunya sumber belajar akan tetapi sebagai mediator dan fasilitator dalam rangka membantu optimalisasi belajar peserta didik.

Berdasarkan hasil observasi dan wawancara dengan pihak sekolah, bahwa dalam meningkatkan mutu pendidikan telah melakukan berbagai upaya-upaya antara lain melengkapi buku-buku perpustakaan, mendisiplinkan dalam proses belajar mengajar baik peserta didik maupun guru, dan mengikutsertakan guru dalam pelatihan-pelatihan, setiap guru mata pelajaran wajib membuat perangkat-perangkat pembelajaran seperti program tahunan, program semester, silabus, rencana pelaksanaan pembelajaran. Namun demikian aktivitas belajar biologi peserta didik masih cenderung rendah. Hasil observasi dan wawancara dengan guru bidang studi biologi. Ditandai banyaknya peserta didik yang belum mencapai kreteria ketuntasan minimal (KKM), dimana KKM mata pelajaran biologi adalah 75 , sebagaimana dapat dilihat pada tabel dibawah ini :

TABEL 1

DATA NILAI HASIL BELAJAR PESERTA DIDIK

\begin{tabular}{ccccc}
\hline No & Nilai & Kriteria & Jumlah & Persentase \\
\hline 1 & $\geq 75$ & Tuntas & 8 & $38,10 \%$ \\
2 & $<75$ & Tidak Tuntas & 13 & $61,90 \%$ \\
& Jumlah & 21 & $100 \%$ \\
\hline
\end{tabular}

Berdasarkan tabel 1 dapat dilihat bahwa dari 30 peserta didik hanya 8 peserta didik yang tuntas belajar atau sebesar $38,10 \%$ dan yang tidak tuntas ada 13 peserta didik atau $61,90 \%$. Data tersebut dapat dilihat bahwa sebagian besar peserta didik tidak mencapai ketuntasan belajar.

Kemudian didapat dari hasil observasi dan wawancara terkait dengan peserta didik yang tidak tuntas ditemukan beberapa aktivitas antara lain:

1. Peserta didik menganggap pelajaran biologi sebagai pelajaran yang sulit dan rumit apalagi penyampaiannya dengan metode ceramah khususnya pokok bahasan dimensi tiga banyak konsep-konsep yang abstrak.

2. Sering kali ketika diberi kesempatan untuk bertanya peserta didik hanya berdiam, sementara peserta didik belum memahami materi yang disampaikan guru.

3. Ketika guru meminta peserta didik untuk mengerjakan soal, ada peserta didik yang tidak mengerjakan soal

4. Sebagian besar peserta didik yang tidak mengerjakan latihan yang diberikan guru secara mandiri, peserta didik lebih banyak menyalin jawaban yang telah dikerjakan oleh teman atau guru didepan kelas.

5. Beberapa peserta didik tidak dapat mengerjakan latihan bahkan pekerjaan rumah (PR), sementara mereka tidak berusaha untuk membaca buku latihan atau bertanya kepada teman yang dapat mengerjakan latihan.

Melihat permasalahan-permasalahan tersebut, bahawa peserta didik menganggap pelajaran biologi sebagai pelajaran yang sulit dan rumit apalagi penyampaiannya dengan metode ceramah, sebagian besar peserta didik yang tidak mengerjakan latihan yang diberikan guru secara mandiri, peserta didik lebih banyak menyalin jawaban yang telah dikerjakan oleh teman atau guru didepan kelas, maka model pembelajaran kooperatif tipe TPS merupakan salah satu solusi untuk meningkatkan aktivitas dan hasil belajar. Think-pair-share (TPS) dapat memberi peserta didik lebih banyak waktu untuk berpikir, untuk merespon dan saling membantu [5].

Setiap peserta didik akan berpikir dan mempunyai pendapat sendiri dalam menyelesaikan tugas mandiri yang berkaitan dengan tugas pasangan. Sebelum peserta didik masuk kepasangannya sudah mempunyai pendapat atas hasil pekerjaannya, sehingga mereka akan saling bekerja sama dan saling membantu dalam anggota pasangan untuk menyelesaikan tugas mereka. Proses think-pair-share dimulai pada saat guru melakukan demonstrasi untuk menggali konsepsi awal peserta didik. Pada tahap ini, peserta didik diberi batasan waktu ("think time") oleh guru untuk memikirkan jawabannya secara individual terhadap pertanyaan yang diberikan. Dalam penentuannya, guru harus mempertimbangkan pengetahuan dasar peserta didik dalam menjawab pertanyaan yang diberikan. Setiap peserta didik diberikan kesempatan oleh guru untuk berfikir mengenai masalah yang telah diberikan, dengan berfikir peserta didik diharapkan mampu untuk menelaah soal, berfikir menyelesaikan soal dengan cara peserta didik masing-masing, misalnya peserta didik membuat catatan atau coretan-coretan di lembar kerja siswa (LKS) untuk menyelesaikan masalah yang diberikan secara individu yang akan berpikir dan mempunyai pendapat sendiri dalam menyelesaikan tugas mandiri yang berkaitan dengan tugas pasangan. Sebelum peserta didik masuk kepasangannya sudah mempunyai pendapat tentang materi yang dipelajari, sehingga mereka akan saling bekerjasama dan saling membantu dalam anggota pasangan untuk memahami materi dan menyelesaikan tugas mereka.

Model pembelajaran kooperatif tipe TPS disertai metode demonstrasi diharapkan dapat digunakan untuk meningkatkan aktivitas belajar dan meningkatkan ketuntasan belajar peserta didik khususnya mata pelajaran biologi. Sehubungan dengan hal diatas, maka penulis melakukan penelitian yang berjudul sebagai berikut "PENGGUNAAN MODEL PEMBELAJARAN KOOPERATIF TIPE THINKPAIR-SHARE DISERTAI DEMONSTRASI UNTUK MENINGKATKAN AKTIVITAS DAN HASIL BELAJAR BIOLOGI KELAS XII SMK PGRI 1 TERBANGGI BESAR". 
Berdasarkan latar belakang masalah di atas maka dapat dirumuskan permasalahan sebagai berikut:

1. Apakah pembelajaran dengan model kooperatif tipe think-pair-share disertai demonstrasi dapat meningkatkan aktivitas belajar biologi kelas XII SMK PGRI 1 Terbanggi Besar?

2. Apakah pembelajaran dengan model kooperatif tipe think-pair-share disertai demonstrasi dapat meningkatkan hasil belajar biologi XII SMK PGRI 1 Terbanggi Besar?

Adapun tujuan dari penelitian tindakan kelas ini adalah sebagai berikut:

1. Untuk mengetahui peningkatan aktivitas belajar biologi peserta didik setelah menggunakan model pembelajaran kooperatif tipe think-pair-share disertai demonstrasi pada kelas XII SMK PGRI 1 Terbanggi Besar.

2. Untuk mengetahui peningkatan hasil belajar biologi peserta didik setelah menggunakan model pembelajaran koooperatif tipe think-pair-share disertai demonstrasi pada kelas XII SMK PGRI 1 Terbanggi Besar.

Setiap peserta didik akan berpikir dan mempunyai pendapat sendiri dalam menyelesaikan tugas mandiri yang berkaitan dengan tugas pasangan. Dalam belajar kooperatif, peserta didikdibentuk dalam kelompokkelompok yang terdiri dari 4 atau 5 orang untuk bekerja sama dalam menguasai materi yang diberikan guru [5]. Di dalam kelas kooperatif peserta didik belajar bersama dalam kelompok-kelompok kecil yang terdiri dari 4-6 orang peserta didik yang sederajat tetapi heterogen, kemampuan, jenis kelamin, suku/ ras, dan satu sama lain saling membantu [5].

Think-pair-share merupakan suatu cara yang efektif untuk membuat variasi suasana diskusi kelas [2]. Thinking (berpikir): beri kesempatan peserta didik untuk mencari jawaban tugas secara mandiri. Pairing (berpasangan): bertukar pikiran dengan teman sebangku. Sharing (berbagi): berdiskusi dengan pasangan lain (menjadi 4 peserta didik) [3]. Seperti namanya "Thinking", pembelajaran ini diawali dengan guru mengajukan pertanyaan atau isu terkait dengan pelajaran untuk dipikirkan oleh peserta didik, "Pairing", pada tahap ini guru meminta peserta didik untuk berpasang-pasangan, "Sharing", hasil diskusi intersubjektif di tiap-tiap pasangan hasilnya dibicarakan dengan pasangan seluruh kelas [4].

Langkah langkah dalam penerapan TPS yaitu [2]:

a. Langkah 1: berfikir (Thinking)

Guru mengajukan suatu pertanyaan atau masalah yang dikaitkan dengan pelajaran, dan meminta peserta didik menggunakan waktu beberapa menit untuk berfikir sendiri jawaban atau masalah.

b. Langkah 2: berpasangan (Pairing)

Selanjutnya guru meminta peserta didik berpasangan dan mendiskusikan apa yang telah mereka peroleh. Interaksi selama waktu yang disediakan dapat menyatukan jawaban jika suatu pertanyaan yang diajukan atau menyatukan gagasan apabila suatu masalah khusus yang diidentifikasi. Secara normal guru memberikan waktu tidak lebih dari 4 atau 5 menit untuk berpasangan.

c. Langkah 3 : berbagi (Sharing)

Guru meminta pasangan-pasangan untuk berbagi dengan keseluruh kelas yang telah mereka bicarakan. Hal ini efektif sampai sekitar sebagaian pasangan mendapatkan kesempatan untuk melaporkan.

Keunggulan-keunggulan TPS antara lain [1]:

1. TPS mudah diterapkan diberbagai jenjang pendidikan dan dalam setiap kesempatan.

2. Menyediakan waktu berpikir untuk meningkatkan kualitas respon peserta didik.

3. Peserta didik menjadi lebih aktif dalam berpikir mengenai konsep dalam mata pelajaran.

4. Peserta didik lebih memahami tentang konsep topik pelajaran selama diskusi.

5. Peserta didik dapat belajar dari peserta didik lain.

6. Setiap peserta didik dalam kelompoknya mempunyai kesempatan untuk berbagi atau menyampaikan idenya.

\section{B. METODE PENELITIAN}

Rancangan penelitian ini adalah penelitian tindakan kelas, yang bertujuan untuk meningkatkan aktivitas dan hasil belajar biologi peserta didik. Pada penelitian tindakan kelas ini direncanakan sebanyak 2 siklus, setiap siklus terdiri dari 3 pertemuan. Penelitian ini menggunakan model pembelajaran kooperatif tipe TPS disertai demonstrasi. Dalam penelitian ini, kegiatan yang akan dilakukan adalah mengamati atau mengobservasi aktivitas atau perilaku peserta didik dalam proses pembelajaran dan menilai hasil belajar peserta didikyang diukur dengan nilai tes. Tes dilakukan setiap akhir siklus dan observasi dilakukan dengan memberi tanda ceklis pada aspek yang diobservasi dalam lembar observasi.

Instrumen yang digunakan dalam penelitian ini adalah 1) validasi, yaitu suatu ukuran yang menunjukkan tingkat-tingkat kevalidan atau kesahihan sesuatu instrumen. Suatu instrumen yang valid atau sahih mempunyai validitas tinggi. Sebuah instrumen dikatakan valid apabila mampu mengukur apa yang diingikan. 2) Reliabilitas: reliabilitas menyatakan sampai dimana keajegan ketepatan dari hasil pengukuran. Suatu tes dapat dikatakan mempunyai taraf kepercayaan yang kuat jika tes tersebut dapat memberikan hasil yang tetap. 3) Indeks kesukaran item: butir-butir item tes hasil belajar dapat dinyatakan sebagai butir-butir item yang baik, apabila butir-butir item tersebut tidak terlalu sukar dan tidak pula terlalu mudah. 4) Daya pembeda item: daya pembeda item adalah kemampuan suatu butir item tes hasil belajar untuk dapat membedakan (mendiskriminasi) antara testee yang berkemampuan tinggi (pandai), dengan testee yang berkemampuan 
rendah (bodoh) demikian rupa sehingga sebagian besar testee yang memiliki kemampuan tinggi untuk menjawab butir item tersebut lebih banyak yang menjawab betul, sementara testee yang kemampuannya rendah untuk menjawab butir item tersebut sebagian besar tidak dapat menjawab item dengan betul.

\section{HASIL DAN PEMBAHASAN}

Pembelajaran siklus I dilaksanakan sebanyak 3 pertemuan. Berdasarkan hasil observasi maka diperoleh skor rata-rata aktivitas setiap peserta didik dari hasil observasi dengan skor rata-ratadari rata-rata skor maksimum 3. Dan terdapat 28,6\% aktif dalam kategori tinggi, 66,7\% aktif dalam kategori sedang, 4,76\% aktif dalam kategori rendah. Hasil aktivitas belajar peserta didik pada pelaksanaan siklus I diamati dengan menggunakan lembar observasi terstruktur. Data aktivitas peserta didik selama pelaksanaan penelitian pada siklus I sebagai berikut:

TABEL 2.

HASIL OBSERVASI PERSENTASE KETERCAPAIAN INDIKATOR AKTIVITAS PESERTA DIDIK SIKLUS I

\begin{tabular}{ccccc}
\hline \multicolumn{5}{c}{ SIKLUS I } \\
Pertemuan 1 \\
\hline Indikator & $\mathbf{1}$ & $\mathbf{2}$ & 3 & 4 \\
Skor & 60 & $\mathbf{2 1}$ & 63 & 69 \\
$\%$ & 33,33 & $\mathbf{1 1 , 6 7}$ & 35 & 38,33 \\
\multicolumn{5}{c}{ Pertemuan 2 } \\
Indikator & $\mathbf{1}$ & $\mathbf{2}$ & 3 & 4 \\
Skor & 53 & 33 & 66 & 63 \\
$\%$ & 29,44 & $\mathbf{1 8 , 3 3}$ & 36,67 & 35 \\
Indikator & Pertemuan 3 & & \\
Skor & $\mathbf{1}$ & 2 & 3 & 4 \\
$\%$ & 96 & 54 & 75 & 63 \\
Rata-Rata \% & 53,33 & 30 & 41,67 & 35 \\
\hline
\end{tabular}

Keterangan:

Indikator 1 : Memperhatikan penjelasan guru melalui demonstrasi.

Indikator 2 : Memikirkan soal dalam LKS

Indikator $3:$ Berdiskusi dalam pasangan

Indikator 4 : Berbagi hasil diskusi ke seluruh kelas.

TABEL 3

HASIL BELAJAR PESERTA DIDIK SIKLUS I

\begin{tabular}{ccc}
\hline & Komponen Analisis & Nilai Tes \\
\cline { 2 - 3 } Target $\geq 75 \%$ & Tuntas Belajar & $76,19 \%$ \\
peserta didik & Belum Tuntas Belajar & $23,81 \%$ \\
mencapai nilai & Skor Rata-Rata Hasil Belajar & 73,33 \\
$\geq 75$ & Nilai Tertinggi & 100 \\
& Nilai Terendah & 30 \\
\hline
\end{tabular}

Pembelajaran siklus II dilaksanakan sebanyak 3 pertemuan, hasil observasi maka diperoleh skor ratarata aktivitas setiap peserta didik dari hasil observasi dengan skor rata-rata dari rata-rata skor maksimum 3 . Dan terdapat $52,4 \%$ aktif dalam kategori tinggi, $48 \%$ aktif dalam kategori sedang. Hasil aktivitas belajar peserta didik pada pelaksanaan siklus II diamati dengan menggunakan lembar observasi terstruktur. Data aktivitas peserta didik selama pelaksanaan penelitian pada siklus II sebagai berikut:

TABEL 4

HASIL OBSERVASI PERSENTASE KETERCAPAIAN INDIKATOR AKTIVITAS PESERTA DIDIK SIKLUS II

\begin{tabular}{ccccc}
\multicolumn{5}{c}{$\begin{array}{c}\text { SIKLUS II } \\
\text { Pertemuan 1 }\end{array}$} \\
\hline Indikator & 1 & 2 & 3 & 4 \\
Skor & 57 & 33 & 78 & 78 \\
$\%$ & 31,67 & 18,33 & 43,33 & 43,33 \\
Pertemuan 2 & & \\
Indikator & 1 & 2 & 3 & 4 \\
Skor & 66 & 39 & 72 & 72 \\
$\%$ & 36,67 & 21,67 & 40 & 40 \\
Indikator & Pertemuan 3 & & \\
Skor & 1 & 2 & 3 & 4 \\
$\%$ & 108 & 63 & 84 & 66 \\
Rata-Rata \% & 60 & 35 & 46,67 & 36,67 \\
\hline
\end{tabular}

Keterangan:

Indikator 1 : Memperhatikan penjelasan guru melalui demonstrasi.

Indikator 2 : Memikirkan soal dalam LKS Indikator 3 : Berdiskusi dalam pasangan Indikator 4 : Berbagi hasil diskusi ke seluruh kelas.

TABEL 5

HASIL BELAJAR PESERTA DIDIK SIKLUS II

\begin{tabular}{ccc}
\hline & Komponen Analisis & Nilai Tes \\
\cline { 2 - 3 } Target $\geq 75 \%$ & Tuntas Belajar & $90,84 \%$ \\
peserta didik & Tidak Tuntas Belajar & $9,25 \%$ \\
mencapai nilai $\geq$ & Skor Rata-Rata Hasil Belajar & 86,19 \\
75 & Nilai Tertinggi & 100 \\
& Nilai Terendah & 55 \\
\hline
\end{tabular}

\section{Aktivitas Peserta Didik}

Berdasarkan hasil penelitian data persentase ratarata aktivitas peserta didikdalam kooperatif tipe thinkpair-share disertai demonstrasi mengalami peningkatan pada setiap siklusnya.

TABEL 6

HASIL DAN PENINGKATAN AKTIVITAS PESERTA DIDIK PADA SIKLUS I DAN SIKLUS II

\begin{tabular}{ccccccc}
\hline \multirow{2}{*}{ Kategori } & \multicolumn{2}{c}{ SIKLUS I } & \multicolumn{2}{c}{ SIKLUS II } & \multicolumn{2}{c}{ Peningkatan } \\
& N & (\%) & N & (\%) & N & (\%) \\
\hline Tinggi & 6 & 28,6 & $\mathbf{1 1}$ & 52,4 & 5 & 23,8 \\
Sedang & 14 & 66,7 & 10 & 48 & - & - \\
Rendah & $\mathbf{1}$ & 4,76 & - & - & - & - \\
\hline
\end{tabular}

Berdasarkan tabel diatas pada siklus I dari 30 peserta didik terdapat 6 peserta didik aktif dalam kategori tinggi dengan persentase 28,6\%, terdapat 14 peserta didik aktif dalam kategori sedang dengan persentase $66,7 \%$ dan terdapat 1 peserta didik aktif dalam kategori rendah dengan persentase 4,76\% dari data tersebut terlihat bahwa pada siklus I target yang diharapkan sudah tercapai karena peserta didik yang aktif dalam kategori tinggi sudah mencapai $\geq 30 \%$. Pada 
siklus II terdapat 11 peserta didik aktif dalam kategori tinggi dengan persentase $52,4 \%$, dan terdapat 10 peserta didik aktif dalam kategori sedang dengan persentase $48 \%$ dari data tersebut terlihat bahwa pada siklus II target yang diharapkan juga sudah tercapai karena peserta didik yang aktif dalam kategori tinggi sudah mencapai $\geq$ 30\%. Dimana peningkatan peserta didikaktif dalam kategori tinggi yang terjadi dari siklus I hingga siklus II adalah $23,8 \%$ atau 5 peserta didik. Dengan demikian, indikator keberhasilan yang pertama telah tercapai pada siklus I dan siklus II peserta didik aktif dalam kategori tinggi telah mencapai $\geq 30 \%$.

\section{Aktivitas Belajar Peserta Didik}

Untuk indikator memperhatikan penjelasan guru yang disertai demonstrasi diperoleh hasil pada siklus I yaitu $38,7 \%$ dan $42,8 \%$ pada siklus II dengan peningkatan 4,1\%. Untuk indikator memperhatikan penjelasan guru yang disertai demonstrasi, target yang diinginkan telah tercapai yaitu rata-rata aktivitas peserta didik mencapai $\geq 50 \%$. Indikator memikirkan soal dalam LKS diperoleh hasil pada siklus I yaitu 20\% dan $25 \%$ pada siklus II dengan peningkatan $5 \%$. Untuk indikator memikirkan soal dalam LKS, target yang diinginkan telah tercapai yaitu rata-rata aktivitas peserta didik mencapai $\geq 30 \%$. Indikator berdiskusi dalam pasangan diperoleh hasil pada siklus I yaitu $37,78 \%$ dan 43,33\% pada siklus II dengan peningkatan $5,55 \%$. Untuk indikator berdiskusi dalam pasangan, target yang diinginkan telah tercapai yaitu rata-rata aktivitas peserta didik mencapai $\geq 50 \%$. Indikator berbagi hasil diskusi ke seluruh kelas diperoleh hasil pada siklus I yaitu $36,11 \%$ dan $40 \%$ pada siklus II dengan peningkatan 3,89\%. Untuk indikator berbagi hasil diskusi ke seluruh kelas, target yang diinginkan telah tercapai yaitu rata-rata aktivitas peserta didik mencapai $\geq 20 \%$.

\section{Aktivitas Guru dalam Pembelajaran}

Berdasarkan pada pembelajaran siklus I guru terus mengupayakan untuk melakukan perbaikan-perbaikan dalam pembelajaran untuk mencapai pebelajaran yang lebih baik lagi, dengan cara terus berusaha meningkatkan kekurangan-kekurangan yang terjadi pada siklus I antara lain dengan guru terus memotivasi peserta didik dan berusaha memberikan peluangpeluang kepada peserta didik untuk berani mengutarakan berbagai masalah yang peserta didik hadapi secara mandiri terlebih dahulu, dan berbagai pendapatyang ingin disampaikan. Sehingga pada siklus II diperoleh rata-rata aktivitas guru dengan kategori pembelajaran baik.

\section{Hasil Belajar}

Pada siklus I peserta didik yang mencapai KKM sebanyak 16 peserta didik (76,19\%), sedangkan pada siklus II jumlah peserta didik yang mencapai KKM meningkat menjadi 19 peserta didik (90,84\%). Dengan demikian terjadi peningkatan hasil belajar sebesar 14,65\%. Peningkatan ini membuktikan bahwa hasil belajar pada siklus II lebih baik dari siklus I meskipun masih ada 4 peserta didik yang belum tuntas. Bicara mengenai hasil belajar, dalam penelitian kali ini terdapat satu peserta didik yang selalu mendapatkan nilai 100 pada tes akhir siklus I dan juga pada tes akhir siklus II. Saat proses pembelajaran berlangsung peserta didik tersebut mampu memberikan tanggapan terhadap materi yang disampaikan dengan kategori tinggi dan pada saat mengerjakan saol secara mandiri juga tidak terdapat kesalahan.

\section{SIMPULAN DAN SARAN}

Berdasarkan hasil penelitian tindakan kelas dan pembahasan yang telah dikemukakan maka dapat diambil kesimpulan sebagai berikut:

1. Penggunaan model kooperatif tipe think-pair-share disertai demonstrasi dapat meningkatkan aktivitas belajar peserta didik kelas XII SMK PGRI 1 Terbanggi Besar. Hal ini dapat terlihat dari perubahan aktivitas peserta didik pada saat proses pembelajaran yang terlihat dari persentase ketercapaian indikator aktivitas peserta didik meningkat dari setiap siklusnya, persentase peserta didik aktif dalam kategori tinggi pada siklus I sebesar 28,6\% kemudian pada siklus II meningkat menjadi $52,4 \%$, kemudian $48 \%$ (10 peserta didik) aktivitasnya meningkat mejadi kategori tinggi.

2. Penggunaan model kooperatif tipe think-pair-share disertai demonstrasi dapat meningkatkan hasil belajar peserta didik kelas XII SMK PGRI 1 Terbanggi Besar. Hal ini terlihat dari siklus I sebanyak $76,19 \%$ peserta didik telah mencapainilai Kriteria Ketuntasan Minimal (KKM) kemudian pada siklus II meningkat menjadi 90,84\%.

Berdasarkan hasil penelitian yang dilaksanakan dan kesimpulan yang diperoleh maka disarankan:

1. Untuk meningkatkan aktivitas dan hasil belajar biologi peserta didik, maka disarankan kepada guru dan calon guru biologi untuk menggunakan model dan metode yang tepat dalam pembelajaran. Salah satunya dengan menggunakan model kooperatif tipe think-pair-share disertai demonstrasi. Dimana peserta didik secara penuh dapat berpikir secara mandiri sehingga kemampuan awal peserta didik dapat dioptimalkan, menyelesaikan permasalahan yang diberikan, sehingga ke depannya peserta didik juga akan mampu menyelesaikan masalah yang dihadapi dalam kehidupan sehari-hari.

2. Dalam pembelajaran diharapkan guru selalu memberi motivasi dan memberi inovasi baru agar peserta didik tidak jenuh dalam belajar.

3. Kepada para peserta didik diharapkan agar lebih memperhatikan pelajaran dan lebih aktif dalam mengikuti pembelajaran di kelas khususnya 
pelajaran bidang studi biologi. Namun perlu diperhatikan pula sarana dan prasarana yang menunjang serta kesiapan dari masing-masing guru bidang studi guna mendapatkan hasil yang memuaskan.

\section{DAFTAR RUJUKAN}

[1] Adib, M., Penerapan Pembelajaran Kooperatif Dengan Metode Think-Pair-Share Dalam Meningkatkan Prestasi Belajar Siswa Pada Mata Pelajaran Pendidikan Agama Islam Kelas IV SDN Manggis 1 Ngancar Kab. Kediri, Universitas Islam Negeri Malang, Malang, 2010.

[2] Komalasari, K., Pembelajaran Kontekstual Konsep dan Aplikasi, Refika Aditama, Bandung, 2010.

[3] Riyanto, Y., Paradigma Baru Pembelajaran sebagai Referensi bagi Pendidik dalam Implementasi Pembelajaran yang Efektif dan Berkualitas, Kencana Perdana Media Group, Jakarta, 2009.

[4] Suprijono, A., Cooperative Learning Teoridan Aplikasi Paikem, Pustaka Pelajar, Yogjakarta, 2011.

[5] Trianto, Mendesain Model Pembelajaran InovatoifProgresif Konsep, Landasan, dan Implementasinya pada Kurikulum Tingkat Satuan Pendidikan, Kencana, Jakarta, 2010. 